\title{
Performance of boron nitride coated tools and dies
}

\author{
Kaftanoğlu, B. ${ }^{\text {a, }}{ }^{*}$, Dökmetaş, N. ${ }^{a}$ \\ ${ }^{a}$ BOREN Centre of Competence for Boron Coatings, Metal Forming Centre of Excellence, ATILIM University, Ankara, Turkey
}

\begin{abstract}
A B S T R A C T
Boron nitride (BN) has been utilized as a significant coating material for cutting tool applications due to its excellent mechanical and chemical properties. Cutting tools, molds and machine parts are coated with BN with the coating system using a sputtering technology - a physical vapour deposition (PVD) process. Design and manufacture of the equipment is made locally. Physical, mechanical and tribological properties such as thickness, friction coefficient, wear, and adhesion are measured by using calotest, tribometer, profilometer, micro and macro scratch test, and nanohardness devices. The results of characterization of the coatings show that wear resistance and hardness increase and BN coatings provide increased efficiency by creating a value-added manufacturing. In this case, the use of BN-coated tools in machining is expected to be one of the best solutions.
\end{abstract}

(c) 2013 PEI, University of Maribor. All rights reserved.

\section{ARTICLE INFO}

Keywords:

Physical vapour deposition

Coated tools and dies

Boron nitride

Hardness

Wear

*Corresponding author:

bilgink@atilim.edu.tr

(Kaftanoğlu, B.)

Article history:

Received 13 March 2013

Revised 30 August 2013

Accepted 2 September 2013

\section{References}

[1] Pouch, J.J., Alterovitz, S.A. (1990). Synthesis and properties of boron nitride, Vol. 54-55, Trans Tech Publications.

[2] Kimura, Y., Wakabayashi, T., Okada, K., Wada, T., Nishikawa, H. (1999). Boron nitride as a lubricant additive, Wear, Vol. 232, No. 2, 199-206.

[3] Klages, C.-P., Fryda, M., Matthée, T., Schäfer, L., Dimigen, H. (1998). Diamond coatings and cBN coatings for tools, International Journal of Refractory Metals \& Hard Materials, Vol. 16, No. 3, 171-176.

[4] Neo, K.S., Rahman, M., Li, X.P., Khoo, H.H., Sawa, M., Maeda, Y. (2003). Performance evaluation of pure CBN tools for machining of steel, Journal of Materials Processing Technology, Vol. 140, No. 1-2, 326-331.

[5] Jin, M., Watanabe, S., Miyake, S., Murakawa, M. (2000). Trial fabrication and cutting performance of c-BN-coated taps, Surface and Coatings Technology, Vol. 133-134, 443-447.

[6] Zhou, Z.F., Bello, I., Kremnican, V., Fung, M.K., Lai, K.H., Li, K.Y., Lee, C.S., Lee, S.T. (2000). Formation of cubic boron nitride films on nickel substrates, Thin Solid Films, Vol. 368, No. 2, 292-296.

[7] Will, G., Perkins, P.G. (2001). Is there a new form of boron nitride with extreme hardness?, Diamond and Related Materials, Vol. 10, No. 1, 2010-2017.

[8] Deng, J., Wang, B., Tan, L., Yan, H., Chen, G. (2000). The growth of cubic boron nitride films by RF reactive sputter, Thin Solid Films, Vol. 368, No. 2, 312-314.

[9] Bewilogua, K., Keunecke, M., Weigel, K., Wiemann, E. (2004). Growth and characterization of thick cBN coatings on silicon and tool substrates, Thin Solid Films, Vol. 469-470, 86-91.

[10] Hu, C., Kotake, S., Suzuki, Y., Senoo, M. (2000). Boron nitride thin films synthesized by reactive sputtering, Vacuum, Vol. 59, No. 2-3, 748-754.

[11] Cesur, H., Kaftanoğlu, B., Özel, T. (2009). Machining performance of CBN coated cutting tools for die/mold applications, In: Proceedings of $5^{\text {th }}$ International Conference and Exhibition on Design and Production of Machines and Dies/Molds, 263-267, Kuşadasi, Turkey.

[12] Özel, T., Thepsonthi, T., Ulutan, D., Kaftanoğlu, B. (2011). Experiments and finite element simulations on micromilling of Ti-6Al-4V alloy with uncoated and cBN coated micro-tools, CIRP Annals - Manufacturing Technology, Vol. 60, No. 1, 85-88, doi: 10.1016/j.cirp.2011.03.087. 